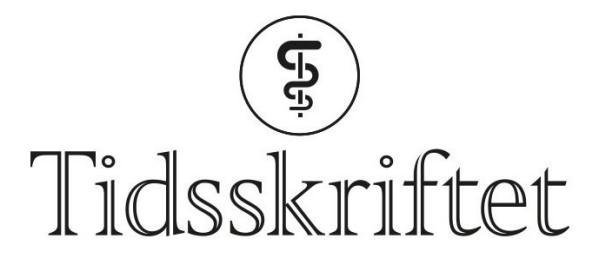

DEN NORSKE LEGEFORENING

\title{
Forbud mot helsehjelp
}

MINILEDER

ARE BREAN

Sjefredaktør

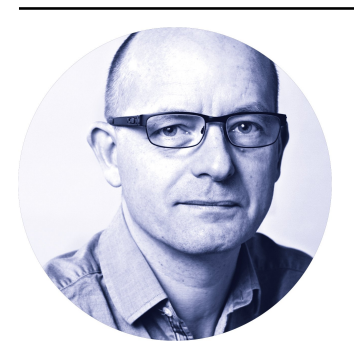

Polen har lenge hatt en av de strengeste abortlovene i Europa. Nå har en ny innstramming ført til et nær totalforbud. 22. oktober 2020 slo landets grunnlovsdomstol fast at alle graviditeter skal fullføres til fødsel, selv når fosteret ikke er levedyktig. Leger som bidrar til abort av ikke-levedyktige fostre, vil heretter kunne bli stilt for retten. Samtidig har landets regjering lenge fors $ø$ kt å vedta et forbud mot seksualundervisning for unge under 18 år. Å gi slik undervisning ønskes likestilt med pedofili og vil kunne gi inntil fem års fengsel.

Kombinasjonen av forbud mot seksualundervisning og nær totalforbud mot abort tegner et dystert bilde for kvinnehelsen i et stadig mer autoritært Polen. Dystert er det også for våre polske legekolleger, som nå risikerer fengselsstraff for å gi helsehjelp. Flere internasjonale organisasjoner har gått hardt ut mot innstrammingen. Det er ikke evidens for at forbud mot abort gir færre aborter, bare at det gir mer lidelse og $ø$ kt helserisiko. Dette er et trist europeisk tilbakeslag for kvinnehelse og kvinners rettigheter.

Publisert: 29. oktober 2020. Tidsskr Nor Legeforen. DOI: 10.4045/tidsskr.20.16.01

(C) Tidsskrift for Den norske legeforening 2020. Lastet ned fra tidsskriftet.no 